\title{
CLINICO-PATHOLOGICAL CORRELATION IN THE CLASSIFICATION OF LEPROSY
}

Anuj Poudel, ${ }^{1}$ Anita Shah, ${ }^{1,}$ Sulochana Khatiwada, ${ }^{2}$ Ashok Samdurkar ${ }^{1}$

\begin{abstract}
INTRODUCTION

Leprosy is one of the major health problems in Nepal, caused by Mycobacterium leprae. Histopathological examination is considered as important tool for proper classification of the disease. This study was carried out to study the histopathological features of leprosy in skin biopsies and classify based on microscopy, bacterial index to correlate with clinical presentations.
\end{abstract}

\section{MATERIAL AND METHODS}

A retrospective observational study was done at Department of Pathology of Universal College of Medical Sciences (UCMS) Bhairahawa for two years from $1^{\text {st }}$ November 2015 to $31^{\text {st }}$ October 2017 and total 68 cases were analysed. Cases in which histopathological diagnosis of leprosy was made or considered differential diagnosis were selected for study. Ridley and Jopling classification was used histologically to make diagnosis of leprosy. Copies of issued histopathology reports, that are preserved in the department routinely were used to obtain data pertaining to age, sex, clinical information and histopathological findings.

\section{RESULTS}

This study included 68 patients diagnosed histologically as leprosy. Histopathological examination of the skin biopsies of 68 patients revealed that, the maximum histopathological cases $28(41.17 \%)$ are BT followed by 15 cases $(22.05 \%)$ of IL (15) and 9 (13.23\%) of TT. Complete parity between clinical diagnosis and histopathology was observed in $55.88 \%$ and disparity was seen in $44.12 \%$.

\section{CONCLUSION}

For proper classification of Leprosy, correlation of clinical and histopathological features along with bacterial index is more useful than considering any of the single parameter.

KEYWORDS Clinical diagnosis, Histopathological diagnosis, Leprosy, Bacillary index

1. Department of Pathology, Universal College of Medical Sciences, Bhairahawa,Nepal

2. Department of Microbiology, Universal College of Medical Sciences, Bhairahawa,Nepal

DOI: http//doi.org/10.3126/jucms.v7i2.27130

\author{
For Correspondence \\ Dr. Anuj Poudel \\ Department of Pathology \\ Universal College of Medical Sciences, \\ Bhairahawa, Nepal \\ Email: dranujpoudel@gmail.com`
}




\section{INTRODUCTION}

Leprosy or Hansen's disease is a slowly progressive infection caused by Mycobacterium leprae. ${ }^{1}$ M. leprae commonly affects the skin and nerves. It can also involve muscles, eyes, bones, testes and internal organs. ${ }^{2}$ Among communicable diseases; leprosy is a leading cause of permanent physical disability. However, early treatment is curative and prevents disability.

Ridley and Jopling (RJ) proposed a histological classification scheme for leprosy in 1960s, which includes early indeterminant leprosy (IL), polar tuberculoid leprosy (TT), borderline tuberculoid leprosy (BT), mid-borderline leprosy (BB), borderline lepromatous leprosy (BL), and polar lepromatous leprosy (LL). ${ }^{4}$ It is further subdivided according to the number of acid-fast bacilli present in the dermis, which is expressed on a logarithmic scale by the bacteriologic index (BI) (Table 1$)^{5}$

\section{Table 1. BI grading}

\begin{tabular}{lll}
\hline Grade & Bacilli & $\begin{array}{l}\text { Examination } \\
\text { OIF }\end{array}$ \\
\hline $1+$ & $1-10$ bacilli in 100 OIF & $100 \mathrm{OIF}$ \\
$2+$ & $1-10$ bacilli in 10 OIF & $100 \mathrm{OIF}$ \\
$3+$ & 110 bacilli in 1 OIF & $25 \mathrm{OIF}$ \\
$4+$ & $10-100$ bacilli in 1 OIF & $25 \mathrm{OIF}$ \\
$5+$ & $100-1000$ bacilli in 1 OIF & $25 \mathrm{OIF}$ \\
$6+$ & $>/=1000$ bacilli in 1 OIF & $25 \mathrm{OIF}$ \\
\hline
\end{tabular}

In 1982, World Health Organization (WHO) recommended the use of two different regimens of multidrug therapy for the treatment of leprosy on the basis of the RJ classification. Accordingly, IL, TT, and BT cases of leprosy are included in paucibacillary $(\mathrm{PB})$ treatment regimen, and $\mathrm{BB}, \mathrm{BL}$, and $\mathrm{LL}$ cases of leprosy are included in multibacillary $(\mathrm{MB})$ treatment regimen. Similarly, a BI value $\geq 2$ at any skin site is considered as MB leprosy and a BI value $<2$ as PB Leprosy. ${ }^{4}$

Despite its low communicability leprosy continues to be an important public health problem in most parts of the world including Nepal. ${ }^{6}$ On $19^{\text {th }}$ January 2010, the Government of Nepal declared the elimination of leprosy, after achieving a prevalence rate of 0.89 per 10,000 populations. ${ }^{7}$ However, disease is not eradicated completely and still prevalent in various areas and a common clinical condition among the medical visits. ${ }^{8}$ Along with clinical judgment skin biopsies help to diagnose different types of leprosy and also separate it from other granulomatous lesions. ${ }^{9}$ This study was done at UCMS-TH to find out the clinical and histopathological correlation in the classification of leprosy along with bacillary index.

\section{MATERIALAND METHODS}

A retrospective observational study was done at Department of Pathology of Universal College of Medical Sciences (UCMS) Bhairahawa for two years from $1^{\text {st }}$ November 2015 to $31^{\text {st }}$ October 2017. Ethical approval was taken from the institutional review committee of UCMS-TH. Cases in which histopathological diagnosis of leprosy was made or considered differential diagnosis irrespective of age and sex of the patient or nature of the lesion were selected for study. Those cases where leprosy was suspected clinically but histopathology did not agree with the diagnosis were not included. The Ridley-Jopling classification was used histologically to make diagnosis of leprosy. Cases of indeterminate leprosy were also included. The requisition forms accompanying the biopsy specimen as well as the copy of issued histopathology reports that are preserved in the department routinely were used to obtain data pertaining to age, sex, clinical information and histopathological findings. The microscopic descriptions of the slides given in the reports were also studied to obtain the information. We did not review the Haematoxylin and Eosin stained or Fite stained sections. Data were analyzed with the help of SPSS statistics version 20

\section{RESULTS}

During the study period, 68 biopsy specimens were studied which included 44 males and 24 females with male to female ratio of 1.8:1. Age group of the patient ranges from 12 to 75 years. Histopathological examination of the skin biopsies of 68 patients revealed that, the maximum histopathological cases $28(41.17 \%)$ were BT followed by 15 cases $(22.05 \%)$ were IL and 9 cases $(13.23 \%)$ were TT which is shown in Table 2 .

\section{Table 2. Histological classification of leprosy}

\begin{tabular}{lcc}
\hline $\begin{array}{l}\text { Histological } \\
\text { Classification }\end{array}$ & No of Cases & Percentage \\
\hline TT & 9 & $13.23 \%$ \\
BT & 28 & $41.17 \%$ \\
BB & 2 & $2.94 \%$ \\
BL & 5 & $7.35 \%$ \\
LL & 8 & $11.76 \%$ \\
HISTOID & 1 & $1.47 \%$ \\
IL & 15 & $22.05 \%$ \\
\hline
\end{tabular}

Table 3 shows bacillary index in various types of leprosy. Fite stain was done in all 68 cases, out of which 23 cases $(33.8 \%)$ showed positivity. Bacillary index was $\leq 2$ in tuberculoid type whereas it was $\geq 2$ in lepromatous type. 
Table 3. Bacillary index with histopathological correlation

\begin{tabular}{ccccccccc}
\hline BI & TT & BT & BB & BL & LL & HISTOID & IL & TOTAL \\
\hline 0 & 9 & 21 & 2 & 0 & 0 & 0 & 13 & 45 \\
$1+$ & 0 & 4 & 0 & 0 & 0 & 0 & 1 & 5 \\
$2+$ & 0 & 3 & 0 & 2 & 0 & 0 & 0 & 5 \\
$3+$ & 0 & 0 & 0 & 1 & 0 & 0 & 1 & 2 \\
$4+$ & 0 & 0 & 0 & 1 & 0 & 0 & 0 & 1 \\
$5+$ & 0 & 0 & 0 & 1 & 3 & 0 & 0 & 4 \\
$6+$ & 0 & 0 & 0 & 0 & 5 & 1 & 0 & 6 \\
Total & $\mathbf{9}$ & $\mathbf{2 8}$ & $\mathbf{2}$ & $\mathbf{5}$ & $\mathbf{8}$ & $\mathbf{1}$ & $\mathbf{1 5}$ & $\mathbf{6 8}$ \\
\hline
\end{tabular}

Table 4 shows the clinico-histopathological correlation in the diagnosis of Leprosy. Among 68 cases on clinical leprosy spectrum based on Ridley and Jopling scale revealed maximum 25 cases $(36.7 \%)$ of BT followed by 21 cases (30.8\%) of TT, 15 cases (22\%) of LL, four cases $(5.8 \%)$ of IL and least three cases $(4.4 \%)$ of BL. Complete agreement between clinical diagnosis and histopathology was observed in $55.88 \%$ and disagreement was seen in $44.12 \%$ of cases as shown in Table 5.

\section{Table 4. Clinico-histopathological correlation}

\begin{tabular}{lcccccccc}
\hline Clinical & \multicolumn{7}{c}{ Histological Diagnosis } \\
\hline Diagnosis & TT & BT & BB & BL & LL & HISTOID & IL & Parity \% \\
\hline TT (21) & 7 & 9 & 2 & 0 & 0 & 0 & 3 & $33.33 \%$ \\
BT (25) & 2 & 19 & 0 & 0 & 0 & 0 & 4 & $76 \%$ \\
BB (0) & 0 & 0 & 0 & 0 & 0 & 0 & 0 & $0 \%$ \\
BL (3) & 0 & 0 & 0 & 1 & 1 & 0 & 1 & $33.33 \%$ \\
LL (15) & 0 & 0 & 0 & 4 & 7 & 1 & 3 & $46.66 \%$ \\
HISTOID (0) & 0 & 0 & 0 & 0 & 0 & 0 & 0 & $0 \%$ \\
IL (4) & 0 & 0 & 0 & 0 & 0 & 0 & 4 & $100 \%$ \\
\hline
\end{tabular}

Table 5. Complete agreement-clinical diagnosis \& histopathology

\begin{tabular}{lccc}
\hline \multicolumn{2}{c}{ Clinical Cases } & \multicolumn{2}{c}{ Complete Parity } \\
\hline TT & 21 & 7 & $33.33 \%$ \\
BT & 25 & 19 & $76 \%$ \\
BB & 0 & 0 & $0 \%$ \\
BL & 3 & 1 & $33.33 \%$ \\
LL & 15 & 7 & $46.66 \%$ \\
HISTOID & 0 & 0 & $0 \%$ \\
IL & 4 & 4 & $100 \%$ \\
Total & 68 & 38 & $55.88 \%$ \\
\hline
\end{tabular}

\section{DISCUSSION}

Among various classifications of leprosy, most commonly accepted classification by research workers is that of Ridley and Jopling which is primarily based on immunity but has been correlated with clinical, histopathological and bacteriological findings. ${ }^{10}$ In our study Leprosy was found more common in males 44 compared to female 24 with male to female ratio $1.8: 1$. This finding is similar to other finding which shows male to female ratio 1.4 : 1 to $2: 1$. $^{11-13}$

Clinical spectrum of leprosy in the present study revealed the maximum histopathological cases of BT was 28 (41.17\%) followed by IL 15 (22.05\%) and TT 9 (13.23\%). Similar type of result was observed by the study done by Badhan $\mathrm{R}$ et $\mathrm{al} .{ }^{14}$ In our study Fite stain was done in 68 cases, out of which $33.8 \%$ show positivity. Bacillary index was $\leq 2$ in tuberculoid type whereas it is $\geq 2$ in lepromatous type which is similar to findings of other studies. ${ }^{11,15}$

In this study complete agreement between clinical diagnosis and histopathology was observed in $55.88 \%$ and disagreement was seen in $44.12 \%$ of cases. Various studies showed clinicopathological concordance from $53 \%$ to $65 \%{ }^{16}$ The disparity between clinical and histopathological diagnosis is due to overlapping spectrum of Leprosy. Clinical examination only reflects gross morphology of overlying epidermis. Histopathological examination is more precise and response of the tissue can be observed not only in the epidermis but also in the underlying dermis and hypodermis. Therefore it is logical to except some degree of disparity between clinical and histopathological features in various types of leprosy.

\section{CONCLUSION}

Majority of the leprosy cases especially polar forms can be diagnosed clinically. Other forms of leprosy mainly borderline can pose diagnostic dilemma. In developing countries like Nepal, where the advanced diagnostic facility are still lacking, histopathological evaluation along with BI play a vital role for further typing of leprosy cases.

\section{ACKNOWLEDGEMENTS}

We would like to acknowledge to all the staffs of Department of Pathology, Universal College of Medical Sciences, Bhairahawa, Nepal. 


\section{REFERENCES}

1. Kumar, Vinay, Abul K. Abbas, and Jon C. Aster. Robbins and Cotran Pathologic Basis of Disease. Ninth edition. Philadelphia, PA: Elsevier/Saunders, 2015.

2. Park JE, Park K. Epidemiology of communicable diseases. In: Preventive and Social Medicine. Jabalpur Banarasidas Bhanol; 1991.p. 215-25

3. Bennett BH, Parker DL, Robson M. Leprosy: Steps along the Journey of Eradication. Public Health Rep. 2008; 123:198-205.

4. Parkash O. Classification of leprosy into multibacillary and paucibacillary groups: An analysis. FEMS Immunol Med Microbiol. 2009;55:1-5

5. Shivamurthy V, Gurubasavaraj H, Sastry SP, Kumar P. Histomorphological study of leprosy. Afr J Med Health Sci. $2013 ; 12: 68-73$.

6. Jain MC. Leprosy Scenario in Nepal. J Nepal Med Assoc. 2008; 47:259- 63

7. Government of Nepal- Ministry of Health \& Population, Department of Health sciences, Leprosy control division. [Available from http:// dohs.gov.np/?q=node/47].

8. Mathur MC, Ghimire RB, Shrestha P, Kedia SK. Clinico histopathological correlation in leprosy. Kathmandu University Medical Journal. 2011;9(4): 248-51

9. Lucus SB, Ridley DS. The use of histopathology in leprosy diagnosis and research. Lepr Rev.1989;60:257-62

10. Ridley DS, Jopling WH. Classification of leprosy according to immunity: a five- group system. Int J Lepr. 1966; 34: 255.

11. Tiwari M, Ranabhat S, Maharjan S. Clinicohistopathological correlation of leprosy: A retrospective study of skin biopsy specimens in Chitwan Medical College. Inter J Medical Sci Res Prac. 2015;2(1):8-11
12. Rad F, Ghaderi E, Moradi G, Salimzadeh H. The study of disability status of live leprosy patients in Kurdistan province of Iran. Pak J Med Sci. 2007;23:857-61

13. Pathak DT, Jha AK. Clinico -histopathological correlation in leprosy: A tertiary care hospital based study. Our Dermatol Online 2013;4:294-6

14. Badhan R, Kundal RK, Raj RT, Bahl RK, Bal MS. A clinicopathological correlation study of leprosy in a tertiary care teaching institute in Northwest Punjab, India. Am J Med Sci Med. 2014;2:99-108.

15. Chatura KR, Sangeetha S. Utility of Fite-Faraco stain for both mast cell count and bacillary index in skin biopsies of leprosy patients. Indian J Lepr. 2012; 84(3):209-15.

16. Hazarika D, Pawar MK, Dowerah E. A Prospective Study of Clinico-Histopathological Correlation among Leprosy Patients Attending a Tertiary Referral Centre in Assam. This Post Elimination Era. Int J Health Sci Educ. 2017:148-53. 